\title{
O FANTÁSTICO MODERNO NA NARRATIVA RUBINIANA COMO MARCA DE RESISTÊNCIA À EXCEÇÃO DE DIREITO
}

\author{
THE MODERN FANTASTIC IN RUBINIAN NARRATIVE AS A MARK OF \\ RESISTANCE TO THE EXCEPTION OF LAW
}

Recebido: 13/01/2021

\author{
Aprovado: $17 / 05 / 2021$ \\ DOI: $10.18817 /$ rlj.v5i01.2578
}

Publicado: $30 / 07 / 2021$

\author{
Priscila Karina Santos Moreno ${ }^{1}$ \\ Orcid ID: https://orcid.org/0000-0002-3813-2143
}

\begin{abstract}
RESUMO: Este artigo visa analisar como são elaboradas as marcas de resistência frente ao Estado de Exceção de Direito, especificamente a partir do conto Botão de Rosa (1974), de Murilo Rubião. Partimos do entendimento de que a Literatura tem uma função subversiva de denúncia do status quo, que se torna possível quando a narrativa ficcional possibilita a reflexão da realidade social. $O$ estudo visa expor, através das marcas de engajamento da narrativa, como as lógicas de opressão das estruturas soberanas encontram no Direito a sua legitimidade culminando em distopias causadas pelo próprio Estado. Tudo isso por meio de uma investigação que tem a revisão bibliográfica como método de abordagem e possui caráter qualitativo e exploratório. Deste modo, ao descortinar os dramas humanos oriundos dos espaços de existência presentes na narrativa descobrimos, como resultado, que o Estado de Exceção que parece distante, mostra-se muito mais abrangente e próximo do que imaginado.
\end{abstract}

Palavras-chave: Literatura. Resistência. Fantástico. Exceção. Poder.

ABSTRACT: This article aims to analyze how the marks of resistance to the State of Exception of Right are elaborated, specifically from the short story Button of Rose (1974), by Murilo Rubião. We start from the understanding that Literature has a subversive function of denouncing the status quo, which becomes possible when the fictional narrative makes it possible to reflect on social reality. The study aims to expose, through the marks of engagement of the narrative, how the logic of oppression of the sovereign structures finds in the Law its legitimacy culminating in dystopias caused by the State itself. All of this through an investigation that uses the bibliographic review as a method of approach and has a qualitative and exploratory character. In this way, when unveiling the human dramas originating from the spaces of existence present in the narrative, we discover, as a result, that the State of Exception that seems distant, proves to be much more comprehensive and close than imagined.

Keywords: Literature. Resistance. Fantastic. Exception. Power

\section{Considerações Iniciais}

É sabido que a Literatura tem mais que a função estética de expor o belo por meio das palavras. A ela muitas vezes, atribui-se a difícil missão de possibilitar a reconstrução dos lugares de sentido, questionando e sendo marca de resistência

\footnotetext{
1 Mestre em Letras pela Universidade Federal do Maranhão. Pós-Graduada em Direito Penal e Processual Penal, pela Universidade Cruzeiro do Sul (2021), e em Direito do Trabalho e Processual do Trabalho (2017) e Direito Público (2016), pela Faculdade Damásio de Jesus. Bacharela em Direito pela Universidade Federal do Maranhão, UFMA. Licenciada em Letras - Línguas Portuguesa e Espanhola e respectivas Literaturas, pela Universidade Federal do Maranhão, UFMA. Investigadora de Polícia Judiciária, atuando como Assessora Jurídica na Secretaria Estadual de Segurança Pública do Maranhão; Professora Técnica Especialista de Língua Espanhola da Secretaria Estadual de Educação do Maranhão. Áreas de atuação: Língua e Literatura. E-mail: priksm@hotmail.com
} 
das ambivalências ocasionadas no âmago das sociedades e, sem perder sua dimensão estética, apresentar uma dimensão ética, segundo a qual há uma realidade contraditória a ser questionada e combatida (BOSI, 2002). À Literatura também cabe a função de denúncia das distopias, que, via de regra, estão dominadas por senso comum teórico e disciplinam, anonimamente, a produção e comportamento social.

Assentimos a ideia de que a sensibilidade e proximidade da Literatura para com a realidade humana são inegáveis e que quem escreve algo se insere, mesmo que não o sinta, numa tradição que não é apenas literária, mas também social, filosófica, moral, religiosa, e, dentre outros aspectos, jurídica, transpondo para o plano da narrativa, toda a experiência do mundo que desde sempre foi representada - e criada - dentre outras formas, por ela própria.

Parte-se da ideia de que a Exceção de Direito², termo criado inicialmente por Walter Benjamin quando este asseverou que "a maior lição da tradição dos oprimidos é de que o Estado de Exceção é na verdade a regra geral" (1985, p.9), transformou-se em verdadeiro plano político nas sociedades democráticas hodiernas, notadamente no momento em que esta distopia - que a priori fora compreendida como uma medida essencialmente temporal - converteu-se em regra, nos dias atuais (AGAMBEN, 2007, p. 09) e, enquanto novo modelo político se pauta numa experiência histórica que alija porções expressivas da população da norma constitucional e/ou promove a suspensão dos direitos desses indivíduos diuturnamente.

A Exceção enunciada por Walter Benjamin, nomeada de Estado de Exceção de Direito se torna mais clara se tomarmos por linha de raciocínio que o problema central da soberania não é quem a exerce, mas sim sobre o quê ela é exercida. Neste sentido, a Agamben coube a revisita e ampliação desta teoria. Por isto, conceituações arquetípicas como homo sacer, vida nua, bando, campo, além de outras como biopolítica e biopoder, que de algum modo já tinham sido contempladas nos estudos de Hannah Arendt, Foucault e do próprio Benjamin, ganham nova

\footnotetext{
2 Em termos benjaminianos, podemos, neste contexto, defini-lo como o espaço no qual a exceção torna-se a regra.
} 
conotação para o filosofo italiano ${ }^{3}$. Segundo Agamben, homo sacer "é aquele em relação ao qual todos os homens agem como soberanos" (2007, p.86).

Compreendemos que o conto Botão de Rosa (1974), de Murilo Rubião, tornase uma narrativa valiosa na empreitada de entender como são expostas as marcas de resistência frente às distopias exercidas pelo Estado de Exceção soberano. Muito embora não seja uma obra produzida sob um Estado de Exceção declarado ou de seus correspondentes terminológicos (estado de sítio, lei marcial, plenos poderes, etc.) e períodos em que este tenha se manifestado claramente (guerra, fascismo, ditadura), pode ter seu escopo analisado com base nesta teoria, como será visto a seguir, tendo em vista conseguir perscrutar características deste modelo político que não estão diretamente ligadas ao contexto de guerra, mas que configuram outro tipo de barbárie: a imposição do poder mais exorbitante sob o corpo humano e o tolhimento de seus direitos sociais proporcionado pelo próprio sistema jurídico.

$\mathrm{Na}$ tentativa de mostrarmos pelo viés literário como isto acontece, lançaremos mão da pesquisa bibliográfica, que de acordo com Marconi e Lakatos (2003, p.39), ultrapassa a simples repetição, proporcionando a reflexão sobre um tema por um novo foco e a conquista de deduções individuais, e do procedimento monográfico necessário para o desenvolvimento e abordagem pretendidos na focalização de um tema - pela convicção de que desta maneira os resultados alcançados poderão subsidiar outros trabalhos e casos relacionados.

Para tanto, este estudo estará arquitetado didaticamente da seguinte forma: num primeiro momento iremos considerar o que vem a ser a Exceção para Agamben, após verificaremos como se dão as relações de engajamento e resistência inerentes à escrita, continuando exporemos o que vem a ser o fantástico moderno na concepção de Sartre, seguindo apresentaremos o autor do conto para focalizarmos onde ele e sua literatura se localizam no tempo, finalmente analisaremos como o conto Botão de Rosa, de Murilo Rubião, se consagra enquanto elemento de resistência.

\section{O Estado de Exceção Agambeniano}

\footnotetext{
${ }^{3}$ Agamben revisita o estudo sobre biopolítica Foucaultiano e as análises sobre os campos de concentração, elaboradas por Hannah Arendt, para desenvolver os conceitos de homo sacer como veremos adiante.
} 
Na cultura Grega não havia apenas um vocábulo para indicar o que viria a ser a "vida", como ocorre hoje. Assim, o vocábulo "vida" e seu uso eram concebidos de duas formas: Zoé e Bio. Zoé era considerada a vida natural, animal, comum a todos os seres vivos, e Bio, por sua vez, era a vida que só existia no grupo, uma vida racionalizada e qualificada pelo aspecto político que o homem exercia no contexto da comunidade. Desta feita, era como se o homem possuísse dois tipos de "vida": uma que era seu atributo pessoal e natural, desde o momento de seu nascimento, conferindo-Ihe a concepção de ser; outra que só existia no grupo, caso este indivíduo fosse considerado parte dele, ou seja, "cidadão" de um espaço geográfico. Assentado nesse paradoxo entre Zoé e Bio o Estado Moderno foi moldado.

O ponto de partida da construção do Estado é que ele deveria se ancorar na figura do soberano, corporificação do poder absoluto (importante aqui salientar que nascimento do Estado Moderno confunde-se mesmo com a ideia de Absolutismo). Assim, através do contratualismo absolutista ficou tacitamente estabelecido que cada indivíduo cederia o seu direito natural - desde que os demais também o fizessem - conferindo a titularidade da soberania política ao Estado, encontrando-se o soberano sujeito apenas às leis da natureza, posto serem divinas e não podendo ser revogadas pelo poder do Estado. O soberano agiria sobre os súditos para protegê-los.

Com o passar do tempo e evolução da história da humanidade, o modelo de governo absolutista não se mostrou satisfatório para a recém-nascida sociedade capitalista. A partir desta celeuma, outra forma de governo foi criada, a chamada democracia, permitindo o surgimento do chamado Estado Democrático de Direito, que tem por pressuposto fundamental a vida e a dignidade do ser humano (pelo menos em tese). Este Estado Democrático de Direito que tem no Direito um de seus alicerces e bases de constituição, não conseguiu, segundo Agamben, extinguir de forma plena a vontade soberana, que persiste oculta como potência do Estado.

Por ser uma situação contrária ao Estado Democrático, inicialmente a Exceção era utilizada como condição e/ou medida excepcional (como o próprio nome indica) de resolução de situações calamitosas, decretada pelas autoridades quando necessária, a exemplo de emergência nacional, grave ameaça à ordem constitucional democrática, agressão efetiva por forças estrangeiras ou calamidade pública. No entanto, esse mecanismo jurídico-político passou a ser adotado de forma mais abrangente e silenciosa, ganhando uma nova roupagem: todas as 
formas de violência e abusos de poder sobre os indivíduos, arbitrariedades e aviltamento dos direitos humanos adotados no Estado Moderno.

Para Agamben, este Estado despótico de Exceção está na margem de uma divisa imprecisa entre absolutismo e democracia, sendo um primário mecanismo que em nome da proteção, sistematiza e conserva uma aparência jurídico-política para a democracia, gerando, entretanto, um limiar de indecisão entre a vida e o direito.

Agamben abandona o axioma contratual de Estado adotado por Hobbes, para entender como se formam as estruturas da Exceção. Segundo o italiano, o moderno Estado não é a transição do estado de natureza para o estado civil através de um contrato ou uma convenção entre indivíduos, tendo em vista que o fundamento do poder soberano:

Por isto [...] o fundamento do poder soberano não deve ser buscado na cessão livre, da parte dos súditos, do seu direito natural, mas, sobretudo, na conservação, da parte do soberano, do seu direito natural de fazer qualquer coisa em relação a qualquer um, que se apresenta como direito de punir. (AGAMBEN, 2007, p.113)

Agamben se apropria da ideia de biopolítica e biopoder tecidos por Foucault como fundamentos do seu conceito de vida nua, que têm no corpo do homo sacer os elementos onde/nos quais o poder soberano é exercido, e de Hannah Arendt lança mão da concepção de campo, como o espaço onde as arbitrariedades ocorrem, como o lugar onde a Exceção é permanentemente possível.

A biopolítica é uma conceituação desenhada por Foucault, que analisa como as condutas disciplinares, as normas e o poder se modificaram, alteraram e continuam sendo transmutados, sobretudo, a partir do início do século $X X$, transferindo seu foco de ação do indivíduo em si - como acontecia anteriormente-, para a massa, a coletividade, a população. O biopoder se confundiria com a ideia de biopolítica, tendo em vista que este termo comporta, de modo geral, toda a técnica disciplinar usada pelo governo soberano para obtenção do controle dos corpos ou como o filósofo nomeia: as disciplinas ou as técnicas disciplinares:

Este novo mecanismo de poder apoia-se mais nos corpos e seus atos do que na terra e seus produtos. É um mecanismo que permite extrair dos corpos tempo e trabalho mais do que bens e riqueza. E um tipo de poder que se exerce continuamente através da vigilância e não descontinuamente por meio de sistemas de taxas e obrigações distribuídas no tempo; que supõe mais um sistema minucioso de coerções materiais do que a 
existência física de um soberano. Finalmente, ele se apoia no princípio, que representa uma nova economia do poder, segundo o qual se deve propiciar simultaneamente o crescimento das forças dominadas e o aumento da força e da eficácia de quem as domina. (FOUCAULT, 2017, p.105)

Já a ideia de campo foi uma categorização criada por Hannah Arendt para falar dos campos de concentração, mais especificamente o de Auschwitz, maior símbolo do holocausto na época do nazismo. Neste espaço há uma particular condição de vida que tem:

[...] como objetivo último a dominação total do homem [sendo] laboratórios para a experimentação do domínio total [...] [porque] este fim não pode ser atingido senão nas condições extremas de um inferno construído pelo homem. (ARENDT apud AGAMBEN, 2007, p.126, grifos nossos)

Esta filósofa salienta que neste lugar distópico todas as leis se tornam leis flexíveis, sujeitas a serem alteradas de acordo com a vontade daquele que detém o poder, havendo a usurpação dos direitos inerentes ao ser humano. Assim, "a privação fundamental dos direitos humanos manifesta-se, primeiro, e acima de tudo, na privação de um lugar no mundo que torne a opinião significativa e a ação eficaz" (ARENDT, 1990, p.257).

Tendo por sustentáculos as figuras do bando e da soberania o Estado de Exceção se valeria de uma espécie de exclusão inclusiva do ser humano e, por isso, "o que foi posto em bando é remetido à própria separação e, juntamente, entregue à mercê de quem o abandona, e ao mesmo tempo excluso incluso, dispensado e, simultaneamente, capturado" (AGAMBEN, 2007, p.116). Assim a "violência soberana não é, na verdade, fundada em um pacto, mas sobre a exclusão inclusiva da vida nua no Estado. E, como referente primeiro e imediato do poder soberano [...] tem no homo sacer o seu paradigma" (AGAMBEN, 2007, p.113).

\section{As relações de engajamento e resistência inerentes à escrita}

A essa violência constante sofrida nos/pelos corpos dos indivíduos a literatura não se mostrou indiferente, tendo muitos autores a retratado esse fato em suas narrativas, sobretudo a partir do século XX, como é o caso de Murilo Rubião. 
Não nos esqueçamos de que no Brasil deste período a democracia foi interrompida por um golpe civil que a historiografia convencionou denominar como golpe militar, sendo o país marcado por uma forte instabilidade política que subjugou e suprimiu as liberdades individuais. O cenário político e econômico confuso inspirou os literatos à dada propensão e predileção por temas sociais, fazendo, também com que, via de regra, estes se posicionassem e indagassem a realidade imposta do momento. Essa literatura com tons cívicos produziu além da autoficção - que dominou a literatura elaborada no regime militar - uma mistura de gêneros comum à geração de 1970 (época em que Botão de Rosa foi escrita). Não é estranho então entender o porquê de toda a literatura produzida neste período ser afetada pela objurgação, reprimenda, opressão e censura determinada, compulsoriamente, pelo militarismo do período.

Segundo Benôit Denis a obra literária, "qualquer que seja sua natureza e sua qualidade, é engajada no sentido que ela é portadora de uma visão de mundo situada e onde, queira ela ou não, se revela assim impregnada de posição e escolha" (DENIS, 2002, p.36), não existindo, portanto, "literatura desengajada" (DENIS, 2002, p.36). Deste modo, o que caracterizaria desde então o engajamento da obra de arte é "a recusa da passividade [da obra] com relação a este inevitável envolvimento no mundo" (DENIS, 2002, p.36, grifo nosso).

Denis admite que esse engajamento possa se dar como fenômeno historicamente situado (como no caso de questões políticas e sociais, emergentes logo após o pós-guerra, por exemplo); e numa acepção de sentido mais amplo e flexível, que fez de certos escritores defensores de valores universais (como justiça e liberdade) e opositores de poderes constituídos. Segundo Derrida "o lugar do engajamento se representa no cruzamento do testemunho, que consiste dele o 'grau zero'4 $^{4}$ e da ficção, que é dela a modalidade mais alta e possivelmente mais autêntica" (apud DENIS, 2002, p.51).

Tomando de empréstimo a acepção utilizada por Sartre, Benoît assevera que os três componentes semânticos essenciais que determinam o sentido de

\footnotetext{
${ }^{4}$ Na teoria da escrita de Roland Barthes, apresentada em Le Degré zero de l'écriture (1953), existe um espaço nulo na escrita histórica que se chama escrita branca ou grau zero da escrita, conceito que se oporia à definição de literatura. Isto porque esta recorreria a mecanismos gramaticais e estilísticos que se combinam com marcas ideológicas, ao passo que a escrita histórica (écriture) vive neste espaço neutro não submetido às leis da literalidade (BARTHES, Roland. O Grau Zero da Escrita, Edições 70, Lisboa, 1997, p.64).
} 
engajamento são: "colocar em penhor, fazer uma escolha e estabelecer uma ação" (DENIS, 2002, p.51). Estes elementos podem ser travestidos na atitude do artista/literato de escrever/criar a obra, tendo em vista que ao fazê-lo renuncia a uma posição de simples espectador e coloca sua arte a serviço de uma causa, passando a assumir os riscos de sua ação com relação à vida social, política, intelectual e/ou religiosa de seu tempo e que sejam contempladas na obra de arte. Assim "o escritor engajado deseja fazer aparecer seu engajamento na literatura mesmo; [...] deseja fazer de modo que a literatura, sem renunciar a nenhum dos seus atributos, seja parte integrante do debate sócio político" (DENIS, 2002, p.22).

Já Bosi (2002) baseia seus estudos sobre resistência na teoria de Benedetto Croce, relacionada à chamada dialética das distinções, que diferencia as potencialidades humanas em cognitivas e de práxis. Assim, o acesso do espaço da ética para a estética, no que tange à significação, seria exequível quando o locutor/narrador percorresse os preceitos ou valores que movem o homem em sociedade e os externalizasse, mediante uma perspectiva crítica, no processo inerente à criação narratológica, transformando, assim, a arte - literatura, mais especificamente - no oposto do discurso ideológico do homem médio, no avesso de uma variante literária da rotina social que subjaz à própria ideia de resistência. Para o crítico a ideologia seria "um tipo de erro ou uma manipulação do conhecimento" (BOSI, 2010, p.11) devendo, por isso, ser combatida.

Bosi (2002, p.123) declara que não são os valores em si que distinguem um narrador resistente e um militante de mesma ideologia, mas são os modos próprios e específicos de realizar esses valores. Assim, a margem do artista é muito maior que a do 'homem comum' diante de dada situação na realidade concreta/mundo material - pois embora possa partilhar dos mesmos preceitos de outros indivíduos também engajados na resistência e contra antivalores, trabalha seu engajamento de modo peculiar, o que lhe é garantido pelo uso da fantasia, memória e estilística, já que pode imaginar o que 'viria a ser', refletindo isso na obra literária.

Segundo Facina "para o escritor engajado, a obra literária não é uma 'finalidade sem fim', mas sim um meio de se combater por um projeto ético-político, que comumente está associado a valores considerados universais, tais como: justiça e liberdade" (2004, p.24). Coadunando com este entendimento Bosi assevera que a "resistência é um conceito primariamente ético, não estético" (2002, p.118), 
admitindo que a ideia de resistência, quando atrelada à narrativa, dá-se por dois caminhos: a) enquanto tema; e b) como processo inerente à escrita, como veremos a seguir.

a) Resistência como tema da narrativa

Este estilo de resistência ou engajamento literário surge no início do século XIX, entre os anos de 1930 e 1950, como reação ao fascismo e nazismo que se difundiam pela Europa e, posteriormente, por outros continentes do globo. O tema da resistência ligada à arte aparece naquele contexto assumindo caráter antiburguês, não conformista, revolucionário e voltando-se à construção de um novo modelo de humanidade.

Irrompe, por exemplo, a figura do escritor desligado do ideário burguês que busca uma linguagem real, próxima aos valores de liberdade, justiça e progresso, nomeado de "intelectual orgânico" (GRAMSCI apud BOSI, 2002). Segundo Facina esses intelectuais seriam "criados por cada grupo social [e] definido[s] pelo[s] [papéis] que desempenha[vam] no mundo da produção econômica, com a função de dar-Ihes homogeneidade e consciência da própria função, não apenas no campo econômico, mas também no social e no político" (2004, p.26, grifos nossos):

\begin{abstract}
Em outros termos, o intelectual é aquele que, invocando a competência que Ihe reconhecem na sua disciplina, deseja "abusar" dela para a boa causa, quer dizer, para tomar posição no debate público em nome dos valores desinteressados que orientam o seu trabalho de escritor, cientista ou professor. O intelectual tem, portanto, a posição do árbitro e do francoatirador, e usa da sua posição de exterioridade com relação à esfera política para proferir uma palavra ao mesmo tempo autorizada e carismática. (DENIS apud FACINA, 2004, p.23)
\end{abstract}

b) Resistência enquanto processo inerente à escrita

A resistência aqui tratada é a interiorização do processo do fazer narratológico, ostentada em ficções e narrativas escritas, emancipadas de uma linhagem política (mas não necessariamente politizada), produzida pelo narrador e possível por meio do ponto de vista do autor e da estilização da linguagem que deve aprofundar o campo de visão e detectar em certas obras, independente de qualquer cultura política militante, uma tensão interna que as faz resistentes enquanto escrita, no sentido de categorias formadoras do texto narrativo como ponto de vista e 
estilização da linguagem, e, não só, ou não principalmente, enquanto tema (BOSI, 2002, p.129), sendo este estilo:

[...] Um movimento interno ao foco narrativo, uma luz que ilumina o nó inextricável, que ata o sujeito ao seu contexto existencial e histórico. Momento negativo de um processo dialético, no qual o sujeito, em vez de reproduzir mecanicamente o sistema das operações onde se insere, dá um salto para sua posição de distância e, deste ângulo se vê a si mesmo, reconhece e põe em crise os laços apertados que o predem à teia das instituições. (BOSI, 2002, p. 134)

Feitas as considerações necessárias do que seriam engajamento e resistência na literatura se faz mister elucidar que Murilo Rubião usou do chamado fantástico moderno como elemento de resistência em toda a sua literatura. A seguir discorreremos acerca do que vem a ser este gênero para posteriormente vermos como esta categoria se apresentam na obra aqui estudada.

\section{O fantástico moderno como marca de engajamento}

Elaborada por Sartre, a ideia de fantástico moderno, neofantástico ou contemporâneo ${ }^{5}$, diz respeito ao "derradeiro estágio de literatura fantástica" (2005, p.136), e se vale da ideia de não ser mais "necessário e nem suficiente retratar o extraordinário" (SARTRE, 2005, p.136) a partir de mundos surreais, já que este teórico baseia sua teoria na observação do homem moderno, o "objeto mais insólito

5 Este pensamento foi apresentado por Sartre no artigo intitulado "Aminadab: O fantástico considerado como linguagem", originalmente publicado em Cahiers du Sud, № 255, p. 299-303, abril de 1943, e no 256, p. 361-371, maio de 1943. Nele Sartre apresenta uma ideia mais ampla do insólito, que difere do fantástico para Todorov, já que para o crítico búlgaro o fantástico seria uma incerteza, hesitação ao longo da ficção, quanto à veracidade ou não dos eventos narrados: "o fantástico é a vacilação experimentada por um ser que não conhece mais que as leis naturais, frente a um acontecimento aparentemente sobrenatural" (TODOROV, 1981, p.16), ou seja, a "existência de um acontecimento estranho, que provoca uma vacilação no leitor e [...] herói" (TODOROV, 1981, p.16). Ao explicar o que sua concepção de fantástico, Todorov declara: "Estamos agora em condições de precisar e completar nossa definição do fantástico. Este exige o cumprimento de três condições. Em primeiro lugar, é necessário que o texto obrigue ao leitor a considerar o mundo dos personagens como um mundo de pessoas reais, e a vacilar entre uma explicação natural e uma explicação sobrenatural dos acontecimentos evocados. Logo, esta vacilação pode ser também sentida por um personagem de tal modo, o papel do leitor está, por assim dizê-lo, crédulo a um personagem e, ao mesmo tempo a vacilação está representada, converte-se em um dos temas da obra; no caso de uma leitura ingênua, o leitor real se identifica com o personagem. Finalmente, é importante que o leitor adote uma determinada atitude frente ao texto: deverá rechaçar tanto a interpretação alegórica como a interpretação "poética". Estas três exigências não têm o mesmo valor. A primeira e a terceira constituem verdadeiramente o gênero; a segunda pode não cumprir-se. Entretanto, a maioria dos exemplos se cumprem com as três" (TODOROV, 1981, p.19-20). 
de todos" (SARTRE, 2005, p.138), "o único objeto fantástico" (SARTRE, 2005, p.138).

Com uma acepção mais englobante da literatura fantástica, que passa a verificar no homem comum o próprio objeto e inspiração deste gênero, seja pela observação ou captura de suas ações cotidianas, seja pelas relações diárias deste com os demais, Sartre transpõe a responsabilidade do sobrenatural dos fenômenos fantasiosos para o indivíduo, "não o homem das religiões ou do espiritualismo, engajado no mundo apenas pela metade, mas o homem-dado, o homem-sociedade [que] é um microcosmo, é o mundo, toda a natureza" (SARTRE, 2005, p.138, grifo nosso). Assim, o cosmos experimentado neste e por este homem fantástico passa a ser concebido e sentido como a própria realidade vivenciada por cada um dos indivíduos, onde ele próprio está incluso.

A partir da elaboração das figuras do "homem-sociedade", "homem-dado", "homem-natureza", o artista, produtor da obra de arte literária, humaniza o quimérico, tendo em vista que "para encontrar lugar no humanismo o fantástico vai se domesticar tal como os outros gêneros, renunciar às explorações das realidades transcendentes, resignar-se a transcrever a condição humana" (SARTRE, 2005, p. 138) e "ao humanizar-se, o fantástico se reaproxima da pureza ideal de sua essência" (SARTRE, 2005, p.137). Como leciona Schwartz:

\begin{abstract}
A coerência da sintaxe, na cadeia sintagmática, faz com que aos poucos este elemento inicialmente fantástico e estranho continue fantástico (por definição), mas integrado já ao universo sintático-semântico do discurso [...] Instaura-se o fantástico como uma "experiência de limite"; não no sentido atribuído por Poe, de tensão, mas no de contaminação discursiva de realidades. (SCHWARTZ, 1981, p.61)
\end{abstract}

No universo insólito de Botão de Rosa o que se vê é precisamente o que conhecemos: códigos, legislações, ritos processuais - ainda que distópicos - e não elementos extraordinários, sobrenaturais ou maravilhosos. Serão estes elementos comuns ao dia-a-dia, conhecidos por todos nós, que provocarão no espaço narrativo (e no leitor) o assombro e estarrecimento, despojando-se a narrativa, assim, de qualquer tipo de outro artifício:

[...] Nada nas mãos, nada nos bolsos. As pegadas nas margens nós as reconhecemos como nossas. Nada de súcubos, nada de fantasmas, nada 
de homens que choram - há apenas homens, e o criador do fantástico proclama que se identifica com o objeto fantástico. Para o homem contemporâneo, o homem tornou-se uma maneira entre cem de refletir sua própria imagem. (SARTRE, 2005, p.139)

Schwartz (1982) aduz que nas obras de Rubião o paradoxal e ilógico dos acontecimentos é tão somente um recurso deste escritor para questionar o real. Rubião, a partir da elaboração da figura deste "homem do insólito" mostra-nos a realidade de um "mundo denso e fantasmagórico em que espectros alienados vivem num universo agoniante" (SCHWARTZ, 1982, p.58) e no qual "o homem acaba sendo condenado à esterilidade pela própria incapacidade de modificar o mundo sem saída no qual convive" (SCHWARTZ, 1982, p.58).

Desvalidando racionalidade e logicidade as personagens e os contextos vivenciados na trama anularão o nexo e o senso comum. Murilo, a partir deste "homem moderno" ou "ser humano do insólito" pensado por Sartre - que é a personificação do homo sacer posto à margem na Exceção -, consegue transpor para o corpo da ficção sua marca de engajamento, a partir das personagens inseridas na obra.

\section{Sobre Murilo Rubião}

Murilo Eugênio Rubião nascido no ano de 1916, na atual cidade de Carmo de Minas (antiga Silvestre Ferraz), no interior do estado de Minas Gerais, inicia seus estudos em cidades vizinhas à sua, tendo-os concluído no Colégio Arnaldo (grupo Afonso Pena), em Belo Horizonte, capital para onde se mudou com sua família quando tinha apenas sete anos de idade.

Estudou Direito na Universidade Federal deste mesmo estado, bacharelandose na UFMG em 1942. Seduzido pelo jornalismo, uma de suas paixões junto com a literatura, pouco atua no mundo jurídico, tornando-se redator do jornal Folha de Minas e, posteriormente, diretor da Rádio Inconfidência.

Confessadamente dizia não ter aptidão para a poesia, demonstrando sempre inclinação para a prosa, especificamente contos. $O$ conto $O$ ex-mágico foi seu primeiro texto publicado. Lançado inicialmente numa coletânea de textos brasileiros 
na Argentina, em $1946^{6}$, teve sua estreia no Brasil datada de 1947 , não obtendo grande sucesso de público, tampouco de crítica. Apenas em 1974, após a publicação de O pirotécnico Zacarias, é que Murilo passa a atingir uma fama súbita, sendo sua obra vista, nos anos subsequentes, como das mais importantes presenças da literatura fantástica brasileira7. Vale dizer que a publicação de $O$ pirotécnico Zacarias pode ter acontecido também, além da paixão literária que movia autor, como consequência do fato de à época Rubião exercer o posto de organizador do Suplemento Literário do Diário Oficial Minas Gerais, cargo executado desde 1966.

As obras de Murilo Rubião, por uma questão didática, a partir das características nela encontradas, tais como uso do insólito, nonsense ${ }^{8}$, fluxos de consciência, liberdade na estruturação do texto - não convencionalismo -, estariam, pela crítica tradicional, inserida no modernismo (ou pós-modernismo, a depender da linha de entendimento adotada), mais especificamente na terceira geração desta escola literária, sendo sua literatura rotulada pela crítica como realista fantástica ou

\footnotetext{
${ }^{6}$ Conforme informação extraída da página http://www.murilorubiao.com.br, no tópico de acesso vida/ biografia, em 1979, o Suplemento Literário, jornal fundado pelo próprio escritor em 1966, publica entrevista dada a Mirian Chrystus: 'O fantástico tem como base a própria realidade, que é fantástica'. Nessa entrevista já se fala do autor como percussor do realismo fantástico no Brasil e de sua semelhança com escritores hispano-americanos, mas Rubião afirma à entrevistadora que só conheceu Jorge Luís Borges muito tempo depois de ter escrito seus primeiros textos e que a primeira leitura dos textos deste autor não Ihe agradou. Afirmou ainda, que o conto $O$ ex-mágico foi publicado em 1946, numa antologia de contos brasileiros na Argentina, o que pontuaria seu início no realismo mágico antes da corrente hispano-americana: "Antes de Borges fazer contos eu já tinha publicado na Argentina. Ele não deve ter lido, porque os argentinos não nos levam em conta. Mas isso prova que eu comecei antes. Não fui influenciado por eles. Mais fácil é ter ocorrido o contrário".

7 Embora o objetivo do nosso trabalho não seja um estudo detalhado sobre a literatura fantástica, achamos importante, desde já, nos posicionarmos acerca do conceito de Fantástico ao qual nos vinculamos. Entendemos Fantástico na mesma concepção admitida por Sartre, no ensaio Aminadab, ou o fantástico considerado como uma linguagem. O fantástico para este autor tem uma conotação diferente da abordagem tradicionalista defendida por Todorov. Para Sartre não haveria uma oposição, antagonismo, polarização entre o universo sobrenatural e o natural, pois este universo teria uma configuração de completude, totalidade, implicando, por consequência, na inexistência da hesitação defendida por Todorov. Segundo ele, o que explicaria de forma mais adequada sua conformação é a compreensão ou percepção de um mundo às avessas, sendo mais relevante representar a condição, o estado humano, sem obrigatoriamente e indispensavelmente se valer de manifestações ou episódios sobrenaturais (SARTE, Jean-Paul. Aminadab, ou o fantástico considerado como uma linguagem. In: Situações I. Trad. Cristina Prado. São Paulo: Cosac Naify, 2005). Detalharemos melhor esta ideia durante a análise do conto Botão de Rosa (1974), objetivando entender de forma metodológica como o Fantástico aparece no texto e sua importância na configuração do Estado Exceção e resistência frete a esse dentro da ficção sem, contudo, nos aprofundarmos na temática do insólito, pelo fato de, como já dissemos, não ser o objetivo primordial deste trabalho.

8 Termo inglês que significa algo sem lógica, sem sentindo, sem coerência e nexo, ou que indica absurdo literário, sendo uma ampla categorização da literatura que equilibra elementos que fazem sentido com outros que não o fazem, com o efeito de subverter convenções de linguagem ou raciocínio lógico. Este termo está comumente associado ao surrealismo e à Literatura Fantástica.
} 
como fantástico contemporâneo. Sob a forma de insólito, de surrealismo e utilizando-se do fantástico, seus contos evidenciam - sob a aparência de fantasias surrealistas - um olhar de desencanto e desilusão do homem diante das coisas.

A título de exemplo e iniciando por O pirotécnico Zacarias, primeira obra que Ihe concedeu notoriedade, pode-se verificar em seus textos características como a brevidade da existência, sua fugacidade e vazio, retratados a partir de uma narrativa mordaz. Em A noiva da casa azul, temos a meditação sobre a natureza tola e fugaz das relações amorosas, bem como sobre o decurso da temporalidade e brevidade da vida e das coisas. O não assentimento das dissemelhanças entre os seres é visto na fábula Alfredo. Em O convidado, encontra-se uma abissal alegoria do exílio e solitude dos indivíduos e, talvez, da morte. E, por fim, um mini-compêndio sobre a corrupção e desvirtuamento humanos é visto em Os Dragões. Assim, de cada relato pode-se extrair um ou mais significados ocultos, o que indica a natureza aberta e polissêmica da obra de Murilo Rubião.

Segundo Lucas, Rubião foi uma experiência isolada dos contistas do período de 1970, e "uma das mais bem sucedidas manifestações do realismo mágico em nossa prosa de ficção" (1989, p.127). Para o crítico supracitado, o contista mineiro e autor de Botão de Rosa (1974), "criaria em suas narrativas ficcionais um universo enigmático que irá projetar-se nas obras subsequentes” (LUCAS, 1989, p.127). Lucas ainda afirma que "a forma característica com a qual Rubião escreve e cria sua literatura constituiria um desvio na sequência do realismo ontológico existencial que se vai formando no Brasil do pós-guerra" (1989, p.128). Segundo ele, Murilo Rubião:

\footnotetext{
Apoia seu processo narrativo, todo ele, numa linguagem alegórica, fora do tempo profano, mas gravado num tempo e num espaço qualitativamente diferentes, sacralizados pela memória arquétipa. Compõe contos junguianos cujos heróis operam [...] lutando contra um mundo não humanizado, heróis do malogro (1989, p.127-128, grifo nosso).
}

Rubião apresenta o insólito que tem por pilar o próprio cotidiano, a realidade, que por sua vez é absurda, fantástica; afinal não existiria nada mais fantástico ou surreal que a própria vida e morte. Lucas, ao fazer em sua obra um estudo sobre os contos de Autran Dourado compara os escritos destes a uma tradição anterior que viria desde de Murilo, destacando o mistério encontrado nas personagens, a 
melancolia presente na narrativa, a volta aos mitos ou arquétipo e a consciência da morte. Afirma o crítico:

\begin{abstract}
A evanescência e o mistério conferidos aos personagens (numa linha que vem de Murilo Rubião [...]) e o vago tom de melancolia agregado à narrativa indicam um estado de poesia. Não é à toa que as histórias convidam à uma volta aos mitos [...]. E, o que vamos encontrar [...], urdidas para despertar espanto, é a noção revigorada da irreversibilidade da vida e a consciência dramática da morte. [...] Tudo isso, nada mais é, do que o peso metafísico da ficção moderna. (LUCAS, 1989, p.122)
\end{abstract}

Para Murilo, a vida sem o fantástico é ilógica e insana, por isso elegeu esta categoria para denunciar e expor a realidade, a existência, tendo em vista ser mais simples e descomplicado consentir e aceitar o onírico, que conceber o absurdo despautério do mundo real. A fantasia e o irreal se afiguram mais seguros e verdadeiros que o cotidiano e, em função disso, a linguagem do absurdo passa a ser a marca de engajamento, resistência e denúncia de Murilo Rubião.

\title{
O processo de criação da resistência em Botão de Rosa
}

Embora tenha sido escrito no período totalitário brasileiro, a Exceção de Direito identificada na obra não está diretamente ligada ao contexto de guerra, mas configura outro tipo de barbárie: a injusta prisão e execução de Botão de Rosa, músico de nome homônimo ao conto, de uma banda formada por mais doze componentes, e personagem principal do enredo.

Pesa sobre ele, primeiramente, a acusação de engravidar, ao mesmo tempo, todas as mulheres da cidade, ainda que não haja nenhuma prova material do ato, mas, posteriormente a autoridade policial recebe um telefonema do Juiz, autoridade máxima daquele local, e informa a Botão de Rosa que ele estaria sendo acusado por de tráfico de drogas. A cena do detido se ataviando para ser levado pelos policiais à delegacia dá início à trama.

A subalternidade e resignação do protagonista em não se contrapor à prisão causa um estranhamento, já que ele não mostra, em qualquer momento, resistência ao ato. Botão de Rosa, acompanhado dos policiais e dos olhares das mulheres, todas grávidas, atravessa as ruas da cidade até chegar à delegacia onde encontra José Inácio, seu advogado de defesa que talvez seria "a única pessoa a 
desconhecer que fora designado exclusivamente para dar aparência de legalidade ao processo" (RUBIÃO, 2010, p. 145).

A hostilidade da população pela figura de Botão é consignada nos insultos, enxovalhos e agressão física que sofre pelos civis - atiraram-lhe uma pedra quando aparece na sacada logo no início da trama, o que fez com que o sangue lhe escorra pela testa (RUBIÃO, 2010, p.145). Os citadinos pedem que a polícia mate e linche Botão de Rosa. O ódio inicialmente direcionado ao protagonista ganha novas feições e se traduz na agressividade que se volta, também, ao defensor José Inácio, que passa a temer pela própria vida.

Botão de Rosa ao final do conto é executado após o juiz, sentenciá-lo à pena de morte com ajuda da Promotoria e do Tribunal do Júri. Tudo isso ocorre sem ele que tenha tido garantido acesso à ampla defesa e contraditório, ou passado por adequado processo, já que seu advogado mesmo sabendo sobre as irregularidades e ilegitimidades na instrução penal, não consegue defendê-lo, tendo em vista também ter sua vida e carreira ameaçadas pelas autoridades do Estado (juiz, promotor e polícia) que lhe advertiram ser melhor não recorrer da sentença proferida: "Se você não recorrer, Ihe garantiremos uma rendosa banca de advocacia. A promessa é do Juiz" (RUBIÃO, 2010, p. 147). O conto pode ser considerado uma severa crítica à corrupção da justiça tanto da época como dos dias hodiernos.

O componente fantástico é apresentado nas primeiras linhas do enredo, incorporando-se ao habitual, como se fosse seu quinhão. É na retratação dessa condição humana aterrorizante, portanto no fantástico contemporâneo, que verificamos a resistência construída por Rubião em Botão de Rosa, tendo em vista que:

[...] esvai-se qualquer proposta tradicional de leitura de narrativa de suspense - para dar lugar ao indeterminismo sugerido pelo próprio texto. Este modo narrativo [...] opõe-se à teoria formulada por Tzvetan Todorov, onde a dúvida é assumida como condição sine qua non para definir o gênero narrativo em questão. (SCHWARTZ, 1981, p.67-68)

Ao utilizar-se da figura do protagonista e, sobretudo, do advogado José Inácio, Murilo questiona o sistema social distópico - que nega o homem -, fazendo uma radical apologia à liberdade - bem indispensável para assegurar ao indivíduo a sua humanidade: "o leitor descobre que o homem, por sua vez, é apenas um meio" (SARTRE, 2005, p.142) para a configuração da Exceção. 
As argumentações para provar ou não a inocência de Botão de Rosa perdem totalmente o sentido tradicional. As possibilidades de um processo judicial nos moldes do Estado Democrático de Direito ficam diluídas e abafadas no Estado de Exceção Permanente. O que interessa no Estado distópico não é o modo pelo qual o julgamento se articula, mas exclusivamente a punição, a sanção que incidirá ao réu. Na Exceção a pena já fora previamente aplicada, antes mesmo de haver qualquer tipo de instrução processual ou sentença, como se vê abaixo:

Se para o advogado o inquérito policial transbordava de irregularidades, algumas gritantes, como a ausência do auto de prisão em flagrante, maior escândalo lhe causaria o transcurso da instrução criminal, inteiramente fora das normas processuais.

Numa pequena livraria comprou um exemplar da Constituição e todos os códigos, porque talvez tivesse que reformular seu aprendizado jurídico.

Leu até de madrugada. A cada página lida, se abismava com a preocupação do legislador em cercear a defesa dos transgressores das leis penais. Principalmente no capítulo dos entorpecentes, onde não se permitia apresentar determinados recursos, requerer desaforamento. A violação de seus artigos era considerada crime gravíssimo contra a sociedade e punível por tribunal popular. As penas variavam entre dez anos de reclusão, prisão perpétua ou morte.

José Inácio ficou boquiaberto: pena de morte! Ela fora abolida cem anos atrás! Ou teria estudado em outros livros?

Em compensação, ocorrendo a pena capital, admitia-se apelar para instância superior.

Desorientado, abandonou os compêndios. (RUBIÃO, 2010, p.146)

Constata-se na fala de José Inácio a falta de sentido das instituições presentes naquele espaço, bem como seu sistema moral, que concorre para que a Exceção ocorra. A temática do literato, essencialmente circunscrita ao terreno social e jurídico, revela a impotência do homem comum de se afirmar como sujeito diante de forças contra as quais não pode reagir:

José Inácio encolhera-se num canto e, convocado a retornar à tribuna, obedeceu amedrontado, disposto a abreviar suas considerações. Falava com cautela, pesando as palavras, algumas ambíguas, as ideias desconcatenadas e a negar crimes que a própria acusação não atribuía ao incriminado.

Havia total descompasso entre o que afirmava e os apartes do promotor:

- Como poderia engravidar meninas de oito e matronas de oitenta anos?

- Protesto! O delito em pauta se refere unicamente a estupefacientes!

- Os casos de gravidez em massa, ocorridos nesta localidade, não podem ser atribuídos ao denunciado. (RUBIÃO, 2010, p.148) 
Assim, por meio do estranhamento causado pelo fantástico presente no texto, que se verifica no absurdo do processo transposto nas falas de José Inácio, o exercício de reflexão sobre os grandes dramas da humanidade é proporcionado ao leitor, que desperta sua criticidade, por meio de sua sensibilidade promovida pela catarse experimentada pela ficção, passando a questionar o mundo real.

\begin{abstract}
José Inácio reviu, mentalmente, as diversas fases do processo, o cerceamento da defesa do réu, permitido por uma legislação absurda. Sentiu-se na obrigação de apelar e impedir que cometessem terrível iniquidade. Não havia outra opção, contudo vacilava. O duro espancamento de seu constituinte deveria ser tomado como um aviso do que the poderia acontecer, caso apelasse.

E por que trocar as possibilidades de sucesso na sua carreira profissional pela vida de um pobre-diabo que se negava a defender-se e nem se importava com sua própria condenação?

Desistiu do recurso. (RUBIÃO, 2010, p.149)
\end{abstract}

A condenação prévia do protagonista, algo completamente inconcebível fora da realidade subjetiva ficcional, causa no leitor um completo desconforto, um estranhamento, o que o faz indagar sobre a realidade vivida por Botão de Rosa. Esse incômodo provocado pelo efeito insólito da obra, detém a atenção do receptor/público leitor, forçando-o a uma leitura ideológica do texto, levando-o a outra perspectiva sobre as questões ali contempladas, e este passa a questionar se a sanção do músico seria ou não válida; apropriada ou inapropriada; exorbitante e excessiva ou não, como comprovam as falas de Schwartz:

[...] O unheimlich freudiano (sensação sinistra) consegue atingir efeitos sociais bem mais corrosivos. O elemento confirmador dessa possibilidade crítica é o julgamento de Botão de Rosa. As argumentações para provar ou não sua inocência perdem totalmente o sentido tradicional; não pela inverossimilhança que ela propõem (Ex. "As penas variavam entre dez anos de reclusão, prisão perpétua ou morte. José Inácio ficou boquiaberto. Pena de morte! Ela fora abolida cem anos atrás! Ou teria estudado em outros livros?"), mas pela aguçada crítica que o texto propõem. Uma leitura linear de um processo judicial semelhante (que conduziria ao inevitável questionamento: inocente ou culpado?) fica totalmente diluída e abafada pela leitura subjacente. $O$ que interessa é o modo pelo qual o julgamento se articula, desencadeando a percepção de uma denúncia implícita ao texto.

Deste modo vemos que o fantasmagórico e o inverossímil encobrem subtextos que elucidam possibilidades de leitura. E não seria ousado afirmar que o texto 'fantástico', em Murilo Rubião, mascara a mais realista das literaturas (SCHWARTZ, 2000, p.12-13, grifo nosso). 
Aduz Lucas sobre a produção da literatura moderna de forma geral, e de Rubião de forma específica, que "uma das facetas da modernidade da ficção consiste exatamente na delegação que se dá ao leitor de arbitrar o sentido da obra, operando com o autor o andamento da narrativa por domínios psicossociais de onde a significância é extraída" (LUCAS, 1989. p.122). Sendo:

[...] raros os momentos na obra do autor em que o elemento insólito [...] não se converte em trampolim metafórico de uma crítica social. O fantástico como transfiguração lúdica da realidade é [...] a possibilidade de conotação social [que] enriquece o signo narrativo, permitindo que ele se projete além do fenômeno meramente ficcional. (SCHWARTZ, 1981, p.77, grifo nosso)

Candido elucida que o mundo da narrativa ficcional:

[...] pode realçar aspectos essenciais pela seleção dos aspectos que apresenta, dando às personagens um caráter mais nítido do que a observação da realidade costuma sugerir levando-as, ademais, através de situações mais decisivas e significativas do que costuma ocorrer na vida. Precisamente pela limitação das orações, as personagens têm maior coerência do que as pessoas reais (e mesmo quando incoerentes mostram pelo menos nisso coerência); maior exemplaridade; maior significação; e, paradoxalmente, também maior riqueza - não por serem mais ricas do que as pessoas reais, e sim em virtude da concentração, seleção, densidade e estilização do contexto imaginário, que reúne os fios dispersos e esfarrapados da realidade num padrão firme e consistente. (CANDIDO, 2009, p.26-27)

No universo insólito do texto o que se vê é precisamente o que conhecemos: códigos, legislações, ritos processuais - ainda que distópicos - e não elementos extraordinários, sobrenaturais ou maravilhosos, e são esses elementos comuns ao dia-a-dia que provocarão no espaço narrativo e no leitor o assombro e estarrecimento, configurando-se, desta forma, as marcas de resistência na narrativa.

\section{Considerações finais}

A lógica de opressão das estruturas soberanas dos Estados Modernos encontra no Direito a sua legitimidade, constituindo-se como sustentáculo do Estado de Exceção não declarado, que revela as farsas judiciais e suas contradições permitindo que o estado de excepcionalidade seja perpetuado nas sociedades hodiernas através de injustiças provocadas aos cidadãos pelo próprio Estado. Admitimos que a Exceção, enquanto permanente, faz com que o espaço destinado 
ao Direito seja ocupado por uma anomia e substituído pela vida biológica do cidadão, transformando o sujeito no objeto do poder.

Essa exposição da selvageria promovida pelo/no Estado de Exceção permanente permite a aparição de uma literatura engajada elaborada com base no fantástico, emergida de estruturas narrativas repletas de estratégias que tornam as personagens da obra delatoras das selvagerias empregadas seja em sua vida nua, seja nos espaços pelos quais vagam e habitam. Os aspectos aqui destacados propiciaram identificar na leitura proposta as questões suscitadas e afirmar que, por meio dos elementos figurativizados do conto, Murilo Rubião problematiza a própria questão da justiça, através do comportamento das personagens e do enredo ficcional.

Refletindo como literário estampa o arranjo social e jurídico a partir da análise dos contos Botão de Rosa, de Murilo Rubião pudemos constatar a potência éticaestética construída por esse literato que demonstra, por meio dessa narrativa, o empenho em problematizar e nos fazer pensar sobre o comportamento e aplicação do Direito no Estado contemporâneo, bem como interrogar acerca de temáticas políticas e sociais que contemplam o viver em sociedade.

Deste modo, ao descortinar os dramas humanos oriundos dos espaços de existência suscetíveis à violência e/ao despojamento de direitos, o autor nos conduz a pensar criticamente sobre as consequências da ausência destes e sobre a (in)dignidade que pode atingir o ser humano quando isso ocorre. Portanto, a proposta em se observar e pensar a vida nua e o Estado de Exceção agambeniano, em diálogo com o conto supramencionado provou-se produtiva quando se verifica que onde há vida nua há Exceção.

No resultado dos estudos desta pesquisa se observa relevante contribuição para o enriquecimento da crítica literária de Rubião ao ampliarmos a interpretação de sua obra pelo diálogo estabelecido com outras áreas do conhecimento, resultando, dessa forma, em reflexões importantes para os conceitos como a vida nua, que em princípio, poderia ser pensada como sendo uma condição humana restrita ao despojo da lei ou má aplicação desta, que parece distante, mas que a partir da obra desse autor se mostra muito mais abrangente e próxima do que imaginado, compreendendo diversas formas de sofrimento e ultraje aos valores humanos possibilitados diuturnamente no seio das sociedades. 


\section{Referências Bibliográficas}

AGAMBEN. Homo Sacer: o poder soberano e a vida nua I. Tradução de Henrique Burigo. Belo Horizonte: Editora UFMG, 2007.

ARENDT, Hannah. As origens do totalitarismo. Tradução de Roberto Raposo. São Paulo: Companhia das Letras, 1990.

BENJAMIN, Walter. Crítica da violência, crítica do poder. In: BENJAMIN, Walter. Documentos de Cultura, Documentos de Barbárie. Trad. Willi Bolle. São Paulo: Cultrix-Edusp, 1985.

BOSI, Alfredo. Literatura e resistência. São Paulo: Companhia das Letras, 2002.

BOSI, Alfredo. Ideologia e contraideologia: temas e variações. São Paulo: Companhia das Letras, 2010.

CANDIDO, Antônio. Literatura e sociedade: estudos de teoria e história literária. 5.Ed. São Paulo: Editora Nacional, 1976.

FACINA, Adriana. Literatura e sociedade. Rio de Janeiro: Zahar, 2004. Edição do Kindle.

FOUCAULT, Michel. Microfísica do Poder. Rio de Janeiro: Paz e Terra, 2017.

GOULART, Audemaro Taranto. O mundo fantástico de Murilo Rubião. Belo Horizonte: Editora Lê, 1995.

LAKATOS, Eva Maria (org.). Metodologia Científica. São Paulo: Editora Atlas, 2003.

LUCAS, Fábio. Do Barroco ao moderno: vozes da literatura brasileira. São Paulo: Ática, 1989.

RUBIÃO. Murilo. Obra Completa. São Paulo: Companhia de Bolso, 2010. p.144-149.

SARTRE, Jean-Paul. Aminadab, ou o fantástico considerado como uma linguagem. In: . Situações I: crítica Literária. Trad. Cristina Prado. São Paulo: Cosac Naify, 2005.

SCHWARTZ, Jorge. Murilo Rubião: a poética do Uroboro. São Paulo: Ática, 1981.

. Do fantástico como máscara (prefácio da edição, p. 6-13). In. RUBIÃO, Murilo. O convidado. São Paulo: Ática, 2000. 